\title{
Susceptibility of Triatoma brasiliensis from state of Ceará, Northeastern Brazil, to the pyrethroid deltamethrin
}

\author{
Ivan Vieira Sonoda ${ }^{1 /+}$, Letícia Sena Diass ${ }^{1}$, Cláudia Mendonça Bezerra ${ }^{3}$, João Carlos Pinto Dias ${ }^{1}$, \\ Alvaro José Romanha², Liléia Diotaiuti ${ }^{1}$ \\ Laboratório de Triatomíneos e Epidemiologia da Doença de Chagas ²Laboratório de Parasitologia Celular e Molecular, \\ Instituto de Pesquisas René Rachou-Fiocruz, Av. Augusto de Lima 1715, 30190-002 Belo Horizonte, MG, Brasil \\ ${ }^{3}$ Secretaria de Estado de Saúde do Ceará, Fortaleza, CE, Brasil
}

\begin{abstract}
After controlling Triatoma infestans in Brazil, other species of triatomine that were considered minor in the transmission of Chagas disease became important. The persistence of Triatoma brasiliensis in Northeastern Brazil, associated with reinfection of domestic environments recently sprayed with pyrethroids, may be a signal of susceptibility alteration of this species to this insecticide. Specimens of T. brasiliensis from the municipality of Tauá, state of Ceará, were captured before and one year after spraying. They were submitted to bioassays using deltamethrin. The $L D_{50}$ ranged from 0.19-0.33 $\mathrm{ng}$ of deltamethrin/nymph. The resistance ratio among samples from Tauá varied from 1.16-1.79 in the samples captured before the spraying and 1.00-1.74 in the samples captured one year after spraying, demonstrating that the two populations were equally susceptible to deltamethrin. The small difference in susceptibility between the two captures suggests that $\mathrm{T}$. brasiliensis obtained in the second capture are from new invasions of the domestic environment and that the insecticide did not select resistant individuals. Therefore, it is suggested that T. brasiliensis control be carried out supplementing the regular use of pyrethroids with complementary measures, such as improvement of the dwellings and health education.
\end{abstract}

Key words: Triatoma brasiliensis - pyrethroids resistance - Chagas disease - state of Ceará

The strategy for Chagas disease control consists primarily of interrupting vector transmission by applying residual insecticides in infested residences (Massad 2008). Control activities for triatomines started in Brazil around 1950, by the Serviço National de Malaria. After 1975, these activities became a national control program (Vinhaes \& Dias 2000). However, they only reached all of the endemic areas between 1983-1986. In 1986, with the appearance of dengue epidemics, the Chagas Disease Control Program (CDCP) suffered reductions in its activities but maintained the insecticide spraying in infested residences in many areas of the country (Vinhaes \& Dias 2000).

In 1991, the countries of Latin America, where Chagas disease is endemic, decided to join forces against the disease, forming an international cooperation agreement called the Southern Cone Initiative, which involves Argentina, Brazil, Bolivia, Chile, Paraguay and Uruguay (WHO 2002). With this initiative, the CDCP began to prioritise the areas of Triatoma infestans occurrence and epidemiological vigilance was amplified to cover the areas under controlled vector transmission (Dias et al. 2002).

Financial support: FAPEMIG, Fiocruz, Bayer CropScience

+Corresponding author: ivansonoda@hotmail.com

Received 25 January 2010

Accepted 8 April 2010
With the prioritisation of the areas of $T$. infestans, the principal vector of Trypanosoma cruzi, the prevalence of Chagas disease was reduced from approximately 18 million to the current nine million, in little more than 15 years (Schofield et al. 2006). In addition to this great victory, a marked reduction in the distribution of domestic triatomines, not just of T. infestans, was also achieved, with the resulting interruption of the vector transmission of the disease in widespread areas.

The first countries to be declared free of vector transmission were Uruguay and Chile in 1997 and 1999, respectively (WHO 2002). On June 9, 2006, Brazil was formally declared free of transmission promoted by $T$. infestans and of transfusion transmission of Chagas disease (Schofield et al. 2006). With the elimination of T. infestans, other species of triatomine, until then considered of secondary importance in $T$. cruzi transmission, began to receive more attention (Dias et al. 2002, Costa et al. 2003), principally those native species that predominantly occupy the peridomicile $(\mathrm{P})$, making its control more difficult (Noireau et al. 2005).

Despite the control measures undertaken, based on the biological and ecological characteristics of $T$. infestans, a species well adapted to the residential environment, ubiquitous autochthonal species require control strategies adapted to different conditions, as these vectors can reinfest the dwellings from wild populations. Another concern in the combat of triatomines is the development of insecticide resistance, as more than 500 species of insects and mites have already been listed as resistant to one or more classes of insecticides (Feyereisen 1995, Brogdon \& McAllister 1998). 
Few studies of insecticide resistance have been carried out with triatomines. The first evidence of insecticide resistance in triatomines was reported in Venezuela in the 1970s, in areas of occurrence of Rhodnius prolixus continuously treated with dieldrin (Rocha e Silva 1979). Despite this pioneer study, the first results indicating insecticide resistance to pyrethroids, which are currently used in the control of these insects, were obtained by the Centro de Investigaciones de Plagas e Insecticidas, in Buenos Aires in the 1990s (Vassena et al. 2000). In this research, $R$. prolixus from Venezuela and $T$. infestans from the state of Rio Grande do Sul (RS), Brazil, were comparatively studied. The authors found resistance ratios (RRs) that characterised the populations as possessing initial resistance. $R$. prolixus presented the greatest RRs: 12.4 for cypermethrin and 11.4 for deltamethrin. $T$. infestans from RS presented the smallest RR value, 7.0 for deltamethrin, considered the initial resistance. Recently, Sonoda et al. (2009) studied samples of T. infestans from four locations in RS and found RR values that classified the samples as susceptible to deltamethrin.

Currently, insecticide resistance in T. infestans is found in Argentina, principally in the Salta Province and in Bolivia, in the Provinces of Potosí, Chuquisaca, Cochabamba and Tarija (Zerba \& Picollo 2007). However, there is still need for amplifications of this type of study for other areas and species of triatomines.

Recently, Pessoa et al. (2007), studying 14 samples of Triatoma sordida from Minas Gerais (MG), using bioassays with deltamethrin, observed RRs greater than 5 in five of the study samples. According to OPAS (2005), RR values greater than 5 indicate initial resistance to the tested insecticide. With these results, the insecticide resistance study in triatomines of other areas beyond those already listed for Argentina and Bolivia became more important.

Triatoma brasiliensis is the autochthon species of triatomine most important in the Brazilian Northeast, principally found in the semiarid region (Silveira \& Vinhaes 1999, Dias et al. 2000). This triatomine is native to this region of the country, its control being complicated because the wild populations constantly invade the nearby residences that were treated with insecticides (Diotaiuti et al. 2000).

Studies carried out in the state of Ceará (CE) demonstrate that this species of triatomine can already be found beginning four months after treating the infested residences with residual action insecticide, principally in the area surrounding the dwelling (Diotaiuti et al. 2000, Oliveira Filho et al. 2000), due to successive reinvasions from the wild populations of the species.

Due to the report of $T$. brasiliensis persistence in the municipality of Tauá, CE, even with the CDCP's activities occurring regularly (CM Menezes, unpublished observations), a new necessity has arisen to evaluate samples of this triatomine obtained in the municipality, especially after reports of pyrethroid resistance of $T$. infestans, R. prolixus and T. sordida in various areas. Therefore, the objective of this study was to evaluate the susceptibility to deltamethrin of samples of T. brasiliensis from five locations in the municipality of Tauá, CE.

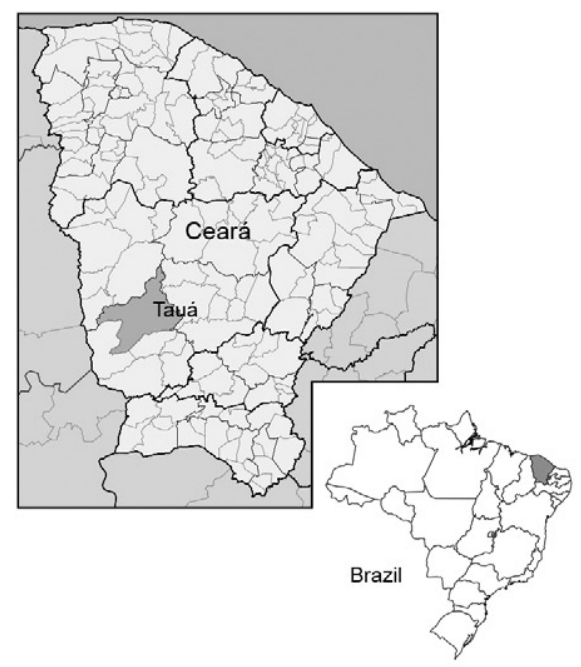

Map of the state of Ceará showing the municipality of Tauá (in grey). Source: IBGE (www.ibge.gov.br/mapas_ibge/pol.php).

\section{MATERIALS AND METHODS}

Samples of T. brasiliensis - The samples of T. brasiliensis studied were obtained from the municipality of Tauá (600'11'S 40¹7’34'”W), CE (Figure), with the assistance of the Ceará Secretary of State for Health. The samples were obtained in the locations of Cachoeira do Júlio, Cachoeira dos Pedrosas, Dormideira, Mutuca and Morada Nova do Thomas, at two times: before spraying the residences with pyrethroid insecticide and one year after spraying. The infestation research was carried out using the hour/man capture method without the use of repellant, capturing all of the insects found in the intradomicile (I) and P In the pre-spraying efforts, T. brasiliensis were captured only in Is, in these locations: Cachoeira do Júlio, Cachoeira dos Pedrosas, Dormideira and Mutuca. One year after spraying, insects were obtained in P (Cachoeira dos Pedrosas, Morada Nova do Thomas and Mutuca) and sylvestral (S) locations (Cachoeira dos Pedrosas).

A laboratorial lineage of T. brasiliensis from Crateús (CE), maintained in isolation for more than 10 generations, without contact with insecticides, was used as a susceptibility reference for the RR calculation of the samples.

Bioassay - In this project, pyrethroid deltamethrin was used (99.1\%, Bayer, Brazil). The CDCP has used pyrethroids in their triatomine control throughout the country for more than 30 years (Dias et al. 2002). Among the existing pyrethroids, the most information is available for deltamethrin, making possible comparisons of our results with those of the literature.

More details of the bioassays are described in Sonoda et al. (2009). The following numbers of T. brasiliensis specimens were obtained from each locale: Cachoeira do Julio (I) (8 adults and 9 nymphs), Cachoeira dos Pedrosas (I) (2 adults and 5 nymphs), Dormideira (I) (0 adults and 2 nymphs), Mutuca (I) (14 adults and 24 nymphs), Cachoeira dos Pedrosas (P) (18 adults and 18 nymphs), Morada Nova do Thomas (P) (0 adults and 3 nymphs), Mutuca (P) 
( 0 adults and 18 nymphs) and Cachoeira dos Pedrosas (S) ( 9 adults and 27 nymphs). All of these samples were reared in the laboratory and bioassays were performed with the second generation from these colonies.

Bioassays consisted of the application of $0.5 \mu \mathrm{L}$ deltamethrin solution to the dorsal regions of fasted firstnymphs, aged five days, using a Hamilton microsyringe with a 50-repetition dispenser. Deltamethrin $(99.7 \%$ purity, Bayer) was serially diluted into concentrations of 0.02 $4.0 \mathrm{ng} / \mu \mathrm{L}$, which were used to produce mortality curves for each sample. A control group was set up for each sample and treated with acetone only. Thirty nymphs were used for bioassays at each insecticide concentration.

The triatomine mortality data were used in the Probit Analysis program (Raymond 1985) to calculate the halflethal dose $\left(\mathrm{LD}_{50}\right)$ of the samples. In this analysis, it was also possible to define the homogeneity of the samples through the angular coefficient (slope). The $\mathrm{LD}_{50}$ values were used in the calculations of the resistance ratios: $\mathrm{RR}=$ $\mathrm{LD}_{50}$ of the field sample/ $\mathrm{LD}_{50}$ of the laboratory sample.

\section{RESULTS}

The control lineage of $T$. brasiliensis used as the susceptibility reference presented an $\mathrm{LD}_{50}$ of 0.19 (ng of deltamethrin/nymph) and slope of 2.92 (Table).

In the pre-spraying capture, the samples of $T$. brasiliensis, obtained only in intradomiciles, had $\mathrm{LD}_{50}$ values ranging from 0.22 (Cachoeira dos Pedrosas) to 0.34 (Dormideira) and RRs ranging from 1.16-1.79. One year after spraying, the samples were captured in $\mathrm{P}$ and, in the case of Cachoeira dos Pedrosas, also in $\mathrm{S}$ environments. The $\mathrm{LD}_{50}$ of this capture varied from 0.19 (Cachoeira dos Pedrosas - S) to 0.33 (Morada Nova do Thomas - P). The RRs varied from 1.00-1.74 (Table). The slope values for the two captures varied from 2.29 (Mutuca - I) to 4.35 (Cachoeira dos Pedrosas).

\section{DISCUSSION}

The current knowledge of triatomine resistance to pyrethroids is limited. Studies have been done principally with $T$. infestans populations from Argentina and
Bolivia. These studies define a critical geographic resistance area for this species, with elevated RR values, which covers the North of Argentina and the South of Bolivia (Vassena et al. 2007, Zerba \& Picollo 2007). In the samples from Argentina, the observed RR values range from 99 (El Chorro) to 133.1 (Salvador Mazza) (Zerba \& Picollo 2007). In Bolivia, the RRs vary from 30.11 (Sonoda et al. 2009) to 154.4 (Vassena et al. 2007, Orihuela et al. 2008). Various samples subjected to the discriminatory dose in Bolivia presented low mortality rates. These results cause concern about the occurrence of pyrethroid resistance in triatomines in other countries, including Brazil.

Due to the natural occurrence of $T$. brasiliensis in $\mathrm{CE}$ and its persistence in areas subjected to regular pyrethroid application (Silveira \& Vinhaes 1999, Dias et al. 2000), with the rapid recolonisation of the domiciliary units (Diotaiuti et al. 2000, Costa et al. 2003, Sarquis et al. 2004, 2006), interest in evaluating pyrethroid resistance in this species using bioassays has increased. Studies have shown that many samples are susceptible to deltamethrin. According to WHO (1994), RR values less than 5 indicate susceptibility to the insecticide. Our $T$. brasiliensis samples from the municipality of Tauá presented RR values less than 2 and are therefore classified as highly susceptible to deltamethrin. Large differences were not observed between the two captures, which leads us to believe that the T. brasiliensis obtained in the second capture are from new invasions of the domestic environments and that the spraying did not promote the selection of resistant individuals.

Even though our findings concerning T. brasiliensis susceptibility are important from the perspective of vector control, it cannot be forgotten that they are valid only for the samples from Tauá and cannot be extrapolated for other locations or populations of this species. Because of this and taking into consideration the ubiquitous presence of $T$. brasiliensis, monitoring insecticide resistance in every population of this species is fundamental, as proposed by Rocha e Silva (1979), as a strategic control measure, but this was never implemented in Brazil. Re-

TABLE

$\mathrm{LD}_{50}$, slope and resistance ratios (RRs) of Triatoma brasiliensis populations from state of Ceará

\begin{tabular}{llccccc}
\hline Capture & T. brasiliensis & LD $_{50}$ & & IC 95\% & Slope & RRs \\
\hline & Reference & 0.19 & 0.16 & 0.23 & 2.92 & 1.00 \\
\hline Before spraying & Cachoeira do Júlio (I) & 0.33 & 0.29 & 0.38 & 2.82 & 1.74 \\
& Cachoeira dos Pedrosas (I) & 0.22 & 0.18 & 0.26 & 2.83 & 1.16 \\
& Dormideira (I) & 0.34 & 0.27 & 0.39 & 3.26 & 1.79 \\
\multirow{3}{*}{ After spraying } & Mutuca (I) & 0.30 & 0.26 & 0.39 & 2.29 & 1.58 \\
& Cachoeira dos Pedrosas (P) & 0.24 & 0.20 & 0.30 & 3.23 & 1.26 \\
& Morada Nova do Thomas (P) & 0.33 & 0.27 & 0.44 & 3.58 & 1.74 \\
& Mutuca (P) & 0.30 & 0.24 & 0.46 & 2.58 & 1.58 \\
& Cachoeira dos Pedrosas (S) & 0.19 & 0.17 & 0.22 & 4.35 & 1.00 \\
\hline
\end{tabular}

I: intradomicile; P: peridomicile; S: sylvestral. 
cently, an implementation perspective was put forth by the Coordenação Geral de Laboratórios de Saúde Pública/ Secretaria de Vigilância em Saúde/Ministério de Saúde for a group that monitors the resistance/susceptibility of triatomines to insecticides in Brazil (XXV Annual Meeting on Applied Research in Chagas Disease and XIII Annual Meeting on Applied Research in Leishmaniasis, 20-24 October, 2009, Uberaba/MG), which will enable: (i) amplification of this study to other areas of triatomine occurrence, as well as other species of importance in the epidemiology of Chagas disease and (ii) the establishment of a map with risk areas for Brazilian triatomine resistance to insecticides.

As observed by Pessoa et al. (2007), T. sordida in MG already presents initial resistance to deltamethrin in five locations in the state. They evaluated 14 samples of this species and obtained RRs in five of the samples, varying from 5.4-6.8, which signifies the occurrence of initial resistance. This result may represent only one part of the area of occurrence of this T. sordida resistance. Other locations should be investigated for a better understanding of the distribution of these resistant insects.

We have previously reported the natural occurrence of $T$. brasiliensis in CE and its constant invasion of the domiciliary environment (Diotaiuti et al. 2000). Our data have helped improve the understanding of this dynamic. The susceptibility of this triatomine to deltamethrin is not a limiting factor for its frequent invasion of the domiciliary environment. Diotaiuti et al. (2000) determined that the $\mathrm{P}$ is reinfested three months after pyrethroid application and that the I is free of infestation for more than six months. Another characteristic that makes the control of T. brasiliensis more difficult is that the $\mathrm{P}$ of the rural areas of this state is confused with the caatinga environment (L Diotaiuti, unpublished observations). It becomes difficult to determine, in many cases, where the domestic environment ends and the S environment begins. This narrows even more the proximity of the species' colonies to the domestic environment and therefore facilitates successive reinvasions of houses. We believe that triatomine control in Northeast Brazil should be a joint effort involving the regular application of residual-action insecticides, health education and improvements in the $\mathrm{P}$, which should include trash elimination, distancing of domestic animals' pens from the walls of the residences, cleanliness, elimination of gaps in the walls that facilitate triatomine entrance and maintenance of epidemiological vigilance in the areas where the species occurs.

\section{ACKNOWLEDGEMENTS}

To Bayer CropScience, for providing the deltamethrin insecticide used in the bioassays.

\section{REFERENCES}

Brogdon WG, McAllister JC 1998. Insecticide resistance and vector control. Emerg Infect Dis 4: 605-613.

Costa J, Almeida CE, Dotson EM, Lins A, Vinhaes M, Silveira AC, Beard CB 2003. The epidemiologic importance of Triatoma brasiliensis as a Chagas disease vector in Brazil: a revision of domiciliary captures during 1993-1999. Mem Inst Oswaldo Cruz 98: 443-449.

Dias JC, Machado EM, Fernandes AL, Vinhaes MC 2000. Esboço geral e perspectivas da doença de Chagas no Nordeste do Brasil. Cad Saude Publica 16 (Suppl. 2): 13-34.

Dias JC, Silveira AC, Schofield CJ 2002. The impact of Chagas disease control in Latin America: a review. Mem Inst Oswaldo Cruz 97: 603-612.

Diotaiuti L, Faria Filho OF, Carneiro FCF, Dias JC, Pires HHR, Schofield CJ 2000. Aspectos operacionais do controle do Triatoma brasiliensis. Cad Saude Publica 16 (Suppl. 2): 61-67.

Feyereisen R 1995. Molecular biology of insecticide resistance. Toxicol Lett 82-83: 83-90.

Massad E 2008. The elimination of Chagas' disease from Brazil. Epidemiol Infect 136: 1153-1164.

Noireau F, Cortez MG, Monteiro FA, Jansen AM, Torrico F 2005. Can wild Triatoma infestans foci in Bolivia jeopardize Chagas disease control efforts? Trends Parasitol 21: 7-10.

Oliveira Filho AM, Melo MT, Santos CE, Faria Filho OF, Carneiro FC, Oliveira-Lima JW, Vieira JB, Gadelha FV, Ishihata J 2000. Focal and total residual insecticide spraying to control Triatoma brasiliensis and Triatoma pseudomaculata in Northeast Brazil. Cad Saude Publica 16: 105-111.

OPAS - Organización Panamericana de la Salud 2005. II Reunion técnica latinoamericana de monitoreo de resistência a insecticidas em triatominos vectores de Chagas, OPS, Panamá, 13 pp.

Orihuela PL, Vassena CV, Zerba EM, Picollo MI 2008. Relative contribution of monooxygenase and esterase to pyrethroid resistance in Triatoma infestans (Hemiptera: Reduviidae) from Argentina and Bolivia. J Med Entomol 45: 298-306.

Pessoa GCD, Sonoda IV, Rezende M, Oliveira-Filho AM, Diotaiuti L 2007. Monitoramento da suscetibilidade ao piretróide deltametrina em linhagens de Triatoma sordida (Stal, 1859). XXIII Reunião de pesquisa aplicada em doença de Chagas e leishmanioses, Anais do Congresso, p. 76.

Raymond M 1985. Preséntation d'um programme d'analyse Log-Probit pour micro-ordinnateur. Ser Ent Met Parasitol 22: 117-121.

Rocha e Silva EO 1979. Profilaxia. In Z Brener, Z Andrade, Trypanosoma cruzi e doença de Chagas, Guanabara Koogan, Rio de Janeiro, p. 425-449.

Sarquis O, Morges-Pereira J, Mac Cord JR, Gomes TF, Cabello PH, Lima MM 2004. Epidemiology of Chagas disease in Jaguaruna, Ceará, Brazil. I. Presence of triatomines and index of Trypanosoma cruzi infection in four localities of a rural area. Mem Inst Oswaldo Cruz 99: 263-270.

Sarquis O, Sposina R, de Oliveira TG, Mac Cord JR, Cabello PH, Borges-Pereira J, Lima MM 2006. Aspects of peridomiciliary ecotopes in rural areas of Northeastern Brazil associated to triatomine (Hemiptera: Reduviidae) infestation, vectors of Chagas disease. Mem Inst Oswaldo Cruz 101: 143-147.

Schofield CJ, Jannin J, Salvatella R 2006. The future of Chagas disease control. Trends Parasitol 22: 583-588.

Silveira A, Vinhaes M 1999. Elimination of vector-borne transmission of Chagas disease. Mem Inst Oswaldo Cruz 94 (Suppl. I): 405-411.

Sonoda IV, Pessoa GCD, Cortez MR, Dias JCP, Romanha AJ, Diotaiuti LG 2009. Susceptibility of Triatoma infestans to deltamethrin in Rio Grande do Sul, Brazil. Mem Inst Oswaldo Cruz 104: 668-670. 
Vassena CV, Picollo MI, Orihuela OS, Zerba E 2007. Desarrollo y manejo de la resistencia a insecticidas piretroides en Triatoma infestans: situación en Bolívia. In M Rojas Cortez, Triatominos de Bolivia y la enfermidad de Chagas, Ministério de Salud y Deportes, Programa Nacional de Chagas, La Paz, p. 229-255.

Vassena CV, Picollo MI, Zerba EN 2000. Insecticide resistance in Brazilian Triatoma infestans and Venezuelan Rhodnius prolixus. Med Vet Entomol 14: 51-55.

Vinhaes MC, Dias JC 2000. Chagas disease in Brazil. Cad Saude Publica 16 (Suppl. 2): 7-12.
WHO - World Health Organization 1994. Protocolo de evaluación de efecto insecticida sobre triatominos. Acta Toxicol Argentina 2: 29-32.

WHO - World Health Organization 2002. Insect vectors and human health: report of the Scientific Working Group meetin, WHO, Geneva, 80 pp.

Zerba E, Picollo MI 2007. Resistencia a insecticidas piretroides en Triatoma infestans. In A Rojas de Arias, M Maldonado, Taller del Cono Sur, actualización de la tripanosomiasis americana, Asunción, p. 105-110. 